\title{
Impact of Erodium moschatum (L.) L.'Hér. extracts against some bacteria and fungi species
}

Mostafa Qahtan Mosataf ${ }^{1}$, Sirwan Hassan Salih ${ }^{2 *}$, Talib Ouaid Alkhazraji ${ }^{3}$

${ }^{1}$ Biology Dept., College of Education, University of Tikret, Saladin Province, Iraq.

2Biology Department, College of Education, University of Garmian, Bardesur‘ Kalar, Iraq.

${ }^{3}$ Biology Department, College of Education, University of Tikret, Saladin Province, Iraq.

Received: 07-10-2018; Revised: 23-10-2018; Accepted: 28-10-2018

\begin{abstract}
The effectiveness of Erodium moschatum extracts (ethanol and methanol, water) were tested against pathogenic bacteria (two gram positive: Staphylococcus aureus and Streptococcus lactis and two gram negative: Escherichia coli and Proteus mirabilis) and four pathogenic fungi (Microsprum canis, Trichophyton mentagrophytes, Pencillium chrysogenum and Fusarium oxysporeum). Tannins, flavonoid and glycoside contents were studied by using HPLC technique and their antimicrobial activities were examined. The results showed the extracts efficacy on the tested microbes in which the ethanol with $11.11 \mathrm{~mm}$ methanol with $11.22 \mathrm{~mm}$ diameter were the most effective against the studied bacteria compared with the rest of the studied extracts, either in the fungi it was found that the studied extracts did not have significant differences in their effectiveness against the tested fungi, the results seemed that there are a difference in the concentration of studied active compounds according to the environment (geographical locations) and the difference in the plant parts, rutin showed the highest concentration in the entire plant (Sulaymaniyah) at concentration 22.92ppm compared to the rest of the compounds and Saladin locality and the studied plant part.
\end{abstract}

Keywords: Phytochemical, Bioactivity, Erodium moschatum (L.) L.'Hér. extracts

\section{Introduction}

The genus Erodium belongs to the family Geraniaceae which consist of 11 genus with 850 species, it include 75 species (Wagh et al., 2015), widely distributed in the temperate and subtropical regions of the northern and southern hemispheres, in Iraq the Erodium has 15 species spread throughout the country (Al-Halfi, 2000). Medically some of Erodium species uses in treatment of diseases such as influenza, inflammation, fever, bowel disorders, liver disease, gas repellant and effective anti-oxidation (Bautista et al., 2015). Extracts of some species are also used to inhibit the growth of different microbes (Proestos et al., 2013 and Radulovic et al., 2011) and contain aromatic oils and many effective chemical compounds (Leyton et al., 2015and Igwenyi, 2016). Thus this study aimed to:

- Identify the antimicrobial effectiveness of water and alcohol extracts against pathogenic fungi and bacteria.

- Identification of the active chemical content of flavonoid and tannin using HPLC technique.

- Separation of some effective compounds and study their antimicrobial efficacy.

\section{Materials and Methods}

Plant sampling: Plant specimens of the E. glaucophyllum were collected in different localities of Tikrit (Saladin) and Sulaimania governorate (middle and northeast Iraq) during the flowering period from March-May of 2015 and 2016. Specimens

\footnotetext{
*Corresponding Author:

Prof. Sirwan Hassan Salih,

President Of Garmian University

$\mathrm{PhD}$ in Biology - Botany- Plant Taxonomy

Kurdistan Region-Iraq

Garmian-Kalar, Iraq.

E-mail: herash1966@yahoo.com

do http://dx.doi.org/10.21746/aps.2018.7.11.3
}

were dried at room temperature away from the light (banning optical oxidation) thereafter grinded and placed in dark-airtight cans and kept in frozen until use.

\section{Aqueous Extraction:}

Hot water extracted was done according to Grand, 1988 with some modification done by mixing 40gm of plant powder (aerial plant parts) with $160 \mathrm{ml}$ of distilled water (1: 4 weight: volume) then heated to boiling point $100 \mathrm{C}^{\circ}$ and add it to the plant powder, shaking the mixture and leave to cool down, placed in the refrigerator for 24 hours, then filtrated through several layers of medical gauze and filtrated again through the Buchner funnel by using Whatmann papers No. 1 to get rid of nonpowdered parts and fibers to obtain raw liquid extract, mixture put in the rotary evaporator at a temperature not exceeding $40 \mathrm{C}^{\circ}$ which working on the basis of evaporation under rarefied pressure to obtain a thick layer of extract, the extract has been dried at temperature $\left(30-35 \mathrm{C}^{\circ}\right)$ and then placed in airtight lid bottles and kept freeze until use. Cold water extraction was done in accordance to the previous steps by using cold water rather than hot water.

\section{Ethanol Extraction:}

Ethanol and methanol extract was prepared according to (Grand, 1988) method, as follows: $20 \mathrm{gm}$ of plant powder (aerial plant parts) as

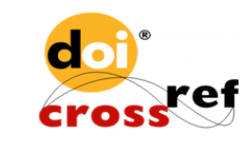


dissolved in $200 \mathrm{ml}$ of ethanol alcohol (80\%) (1:10 weight: volume), the mixture was left in the refrigerator for 24 hours to soak, filtration was done through several layers of gauze and filtered again by using Whatmann papers No. 1 to get rid of nonpowdered parts and fibers, after evaporation it was placed at a temperature under $\left(40 \mathrm{C}^{\circ}\right)$, alcohol was evaporated in the mixture, thick layer of extract was obtained, extract was dried at the temperature (30$35 \mathrm{C}^{\circ}$ ) then put the it in airtight bottles and kept frozen until use. Methanol extraction was folled according to previous steps were followed using of methanol rather than ethanol.

Glycosides Extraction: According to the method of Ukida, 2006, $10 \mathrm{gm}$ of plant powder was added to $100 \mathrm{ml}$ of ethyl alcohol (80\%), mixture leaves for 24 hours in the refrigerator at $4-7 \mathrm{C}^{\circ}$ and filtrated for getting ethanol extract, the extract was concentrated by rotary evaporator to one-third of its volume, $50 \mathrm{ml}$ of ether and $5 \mathrm{ml}$ of lead acetate solution $(0.3$ molarity) were added to the mixture by separation funnel with shaking and pulled the water layer, repeating the process three times and dried water drawn layer at a temperature of $30 \mathrm{C}^{\circ}$ until full drying and then preserved in bottles with airtight lid and kept freeze.

Tannin extraction: Methods of (Ahmad and Nazil, 1989) was followed, $0.5 \mathrm{gm}$ of plant powder was mixed with $50 \mathrm{ml}$ of distilled water and boiled for 30 minutes, mixture filtrated and centrifuging $(2000 \mathrm{r} / \mathrm{m})$ for 20 minutes, the floating part was transferred into volumetric flask $(100 \mathrm{ml})$ then $20 \mathrm{ml}$ of lead acetate solution (4\%) was added to it and complete the volume with distilled water to $100 \mathrm{ml}$, the extract was filtrated and dried by oven $\left(60 \mathrm{C}^{\circ}\right)$ then preserved in airtight bottles and kept freeze until use.

Sample preparation for estimation of flavonoid and tannin content: $1 \mathrm{mg}$ of dry plant sample was dissolved in $150 \mathrm{ml}$ of chloroform and placed it on stirrer hotplate for 10 hours and $0.5 \mathrm{gm}$ of tartaric acid was added to it, it was transferred to ultrasonic for 2 hours and filtrated through filter paper $(0.45 \mathrm{~mm})$ and put in rotary evaporator to remove solvent and take the remaining, methanol was added to it to injection into the HPLC (Seal, 2016).

\section{Separation conditions:}

HPLC column: C18 (25 x 4.6mm I.D. $5 \mu \mathrm{m})$.

Mobile phase

A $=$ MeOH: Acetic Acid: D.W (10: 2: 88) ml

$\mathrm{B}=\mathrm{MeOH}$ : Acetic Acid: D.W (90: 3: 7) ml

Wavelength 348 nanometers

Flow ratio: $1 \mathrm{ml} / \mathrm{min}$.

Temperature $28 \mathrm{C}^{\circ}$

Standard concentration $3 \mathrm{mg} / \mathrm{m}$

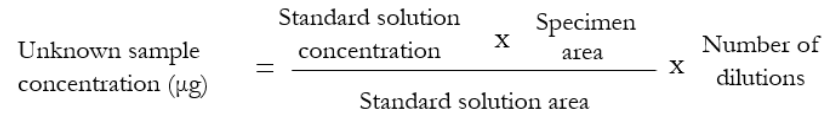

\section{Antimicrobial activity:}

Preparation and sterilization of the stock solution was done according to (Egorove, 1985), in which $1 \mathrm{gm}$ of dry plant extract was dissolved in $10 \mathrm{ml}$ of distilled water to get a stock solution of $100 \mathrm{mg} / \mathrm{ml}$, the solution was sterilized to get rid of the bacterial contaminants, the solution was used as a source of the preparation of the dilutions 25, 50 and 100 $\mathrm{mg} / \mathrm{ml}$. Two species of gram positive bacteria ( $S$. aureus and St. lactis) and two gram negative (E. coli and $P$. mirabilis) were activated directly prior to use, agar diffusion method was used by drilling to observe the microorganisms sensitivity to the studied plant extracts at concentrations 25, 50 and $100 \mathrm{mg} / \mathrm{ml}$, Mueller Hinton Agar media was used to grow the tested fungi.

Three control coefficients (negative, positive for bacteria and positive for fungi) were prepared by:

1. 3 pits was done and taking $(0.5 \mu \mathrm{l} /$ hole $)$ of distilled water and it was placed in the pit assigned to it by three dishes (Three replicates per treatment) (negative control).

2. Tetracycline tablet (30mg) was placed in the dish with three replicates of one treatment (positive control of the bacteria).

3. The first method was repeated except $0.5 \mu \mathrm{l} /$ hole of Nystatin $(100 \mathrm{mg} / \mathrm{ml})$ was took, which acts as an antifungal and antibacterial (positive control of fungi and bacteria)

\section{Results and Discussion}

Antibacterial efficacy of extract concentrations:

The results showed the effectiveness of different extracts (ethanol, methanol, glycoside and tannin, hot water, cold water) at concentrations 25,50 and $100 \mathrm{mg} / \mathrm{ml}$ in inhibition of S. aureus, St. lactis, E. coli and $P$. mirabilis, the diameter of the inhibition area is by $(\mathrm{mm})$ compared to the control 1, 2 and 3 (table 1). The concentrations 50 and $100 \mathrm{mg} / \mathrm{ml}$ of ethanol extract with 11 and $11.5 \mathrm{~mm}$ inhibitor diameter and concentrations 25,50 and $100 \mathrm{mg} / \mathrm{ml}$ of methanol with 11,11 and $11.66 \mathrm{~mm}$ diameter are the most effective in inhibiting bacteria compared to control 1, 3 and all concentrations of extracts, moreover control 2 is the most effective in inhibiting bacteria compared to controls 1 and 3 and all extract concentrations. The concentration of $100 \mathrm{mg} / \mathrm{ml}$ of hot water extract with $10 \mathrm{~mm}$ diameter, cold water extract with $10 \mathrm{~mm}$ diameter, concentrations of 25,50 and $100 \mathrm{mg} / \mathrm{ml}$ of ethanol and methanol with 10,10 and $10 \mathrm{~mm}$ diameter and concentrations of glycosides 10.67, 10.67 with $10 \mathrm{~mm}$ diameter are the most effective in inhibiting species $S$. aureus compared to control 1, 3 and all concentrations. Control 2 with $20 \mathrm{~mm}$ diameter is most effective in inhibition of $S$. aureus, the 
concentrations of 25,50 and $100 \mathrm{mg} / \mathrm{ml}$ of all extraction methods (hot water, cold water and ethanol and methanol, glycoside and tannin) were more effective in inhibiting the species St. lactis compared to control 1 and 2. No significant difference among the concentrations of all extraction methods and control 3. The concentrations 25,50 and $100 \mathrm{mg} / \mathrm{ml}$ of ethanol with 11.33, 10.67 and $12 \mathrm{~mm}$ diameter and methanol with 10,10 and $11.33 \mathrm{~mm}$ diameter and concentrations of 50 and $100 \mathrm{mg} / \mathrm{ml}$ of the glycoside with 10 and $10.67 \mathrm{~mm}$ diameter were the most effective in inhibiting the species E. coli compared to control 1 and all concentrations. The concentrations 50 and $100 \mathrm{mg} / \mathrm{ml}$ of ethanol with 13.33 and $14 \mathrm{~mm}$ diameter and concentration of $100 \mathrm{mg} / \mathrm{ml}$ of methanol with $13.33 \mathrm{~mm}$.
Diameter were most effective in inhibition the species $P$. mirabilis compared to control 1 and 3 and all extracts concentrations, furthermore the control 2 is the most effective in inhibiting the bacteria with a diameter of $19 \mathrm{~mm}$. The results revealed that the ethanol and methanol was the most effective in inhibiting bacteria compared to control and all the studied extracts with average 11.11 and $11.22 \mathrm{~mm}$. the species St. lactis and $P$. mirabilis were most affected by extract concentrations compared to $S$. aureus and E.coli with an average of 10.52 and $9.38 \mathrm{~mm}$ diameter.

\section{Antifungal efficacy of extract concentrations:}

The results showed the efficacy of different extracts (hot water, cold water, ethane, methanol, glycoside, tannin) with concentrations of 25,50 and $100 \mathrm{mg} / \mathrm{ml}$ in inhibition of $M$. canis, T. mentagrophytes, $P$. chrysogenum and F. oxysporeum, the diameter of the inhibition area is by (mm) compared to the control 1, 2 (table 2).

Table 1: Impact of Erodium moschatum extracts on the studied bacterial growth (mm)

\begin{tabular}{|c|c|c|c|c|c|c|c|}
\hline \multirow{2}{*}{ Extract } & \multirow{2}{*}{$\begin{array}{c}\text { Concentration } \\
\mathrm{mg} / \mathrm{ml}\end{array}$} & \multicolumn{4}{|c|}{ Bacteria species } & \multirow{2}{*}{$\begin{array}{c}\text { Average } \\
\text { concentration }\end{array}$} & \multirow{2}{*}{$\begin{array}{l}\text { Average } \\
\text { extract }\end{array}$} \\
\hline & & P. mirabilis & E. coli & St. lactis & S. aureus & & \\
\hline \multirow{6}{*}{ Hot water } & \multirow{2}{*}{25} & A10 & C3.33 & A10 & B8 & 7.83 & \multirow{6}{*}{ bc 8.443} \\
\hline & & $\mathrm{cd}$ & $\mathrm{e}$ & $\mathrm{a}$ & bcd & $\mathrm{de}$ & \\
\hline & \multirow{2}{*}{50} & A10 & B6 & A10 & B7. 33 & 8.33 & \\
\hline & & $\mathrm{cd}$ & $\mathrm{cd}$ & $\mathrm{a}$ & cde & cde & \\
\hline & \multirow{2}{*}{100} & A10 & B6.67 & A10 & A10 & 9.168 & \\
\hline & & $\mathrm{cd}$ & $\mathrm{cd}$ & a & $\mathrm{bc}$ & bcd & \\
\hline \multirow{6}{*}{ Cool water } & \multirow{2}{*}{25} & B7.33 & $\mathrm{C} 2.67$ & A10.67 & $\mathrm{C} 4$ & 6.17 & \multirow{6}{*}{ c 7.667} \\
\hline & & ef & ef & $\mathrm{a}$ & e & $\mathrm{e}$ & \\
\hline & \multirow{2}{*}{50} & A10 & C3.33 & A10.67 & B5.33 & 7.33 & \\
\hline & & $\mathrm{cd}$ & $\mathrm{e}$ & $\mathrm{a}$ & e & de & \\
\hline & \multirow{2}{*}{100} & A10 & B7.33 & A10.67 & A10 & 9.500 & \\
\hline & & $\mathrm{cd}$ & c & $\mathrm{a}$ & $\mathrm{bc}$ & bc & \\
\hline \multirow{7}{*}{ Ethanol } & \multirow{2}{*}{25} & A12 & AB11.33 & B10 & B10 & 10.833 & \multirow{6}{*}{ a 11.111} \\
\hline & & bc & b & $\mathrm{a}$ & $\mathrm{bc}$ & bc & \\
\hline & \multirow[b]{2}{*}{50} & A13.33 & B10.67 & B10 & B10 & 11.000 & \\
\hline & & b & $\mathrm{b}$ & $\mathrm{a}$ & $\mathrm{bc}$ & b & \\
\hline & \multirow{2}{*}{100} & A14 & B12 & C10 & C10 & 11.500 & \\
\hline & & $\mathrm{b}$ & $\mathrm{b}$ & $\mathrm{a}$ & $\mathrm{bc}$ & b & \\
\hline & \multirow{2}{*}{25} & A12 & B10 & A12 & B10 & 11.000 & \\
\hline \multirow{5}{*}{ Methanol } & & $\mathrm{bc}$ & $\mathrm{b}$ & $\mathrm{a}$ & $\mathrm{bc}$ & b & \\
\hline & \multirow{2}{*}{50} & A12 & B10 & A12 & B10 & 11.000 & \\
\hline & & $\mathrm{bc}$ & $\mathrm{b}$ & a & $\mathrm{bc}$ & b & a 11.222 \\
\hline & 100 & A13.33 & BC11.33 & $\mathrm{AB} 12$ & C10 & 11.000 & \\
\hline & 100 & b & b & $\mathrm{a}$ & bc & $\mathrm{b}$ & \\
\hline & & C3.33 & B6 & A12 & A10.67 & 8.00 & \\
\hline & 25 & $\mathrm{~h}$ & $\mathrm{~cd}$ & $\mathrm{a}$ & bc & cde & \\
\hline & & B9.33 & B10 & A12 & $\mathrm{AB} 10.67$ & 10.500 & \\
\hline Glycoside & 50 & de & b & $\mathrm{a}$ & bc & bc & ab 9.722 \\
\hline & 100 & B10 & $\mathrm{AB} 10.67$ & A12 & B10 & 10.668 & \\
\hline & 100 & $\mathrm{~cd}$ & b & $\mathrm{a}$ & $\mathrm{bc}$ & bc & \\
\hline & & B5.33 & C2.67 & A12 & B5.33 & 6.33 & \\
\hline & 25 & $\mathrm{fg}$ & ef & $\mathrm{a}$ & $\mathrm{e}$ & $\mathrm{e}$ & \\
\hline Tannin & 50 & B6 & $\mathrm{C} 2.67$ & A12 & B6.67 & 6.84 & 7 \\
\hline I & 50 & $\mathrm{fg}$ & ef & $\mathrm{a}$ & de & $\mathrm{e}$ & c 7 \\
\hline & & C 5.33 & C4.67 & A12 & B9.33 & 7.83 & \\
\hline & 100 & $\mathrm{fg}$ & ef & $\mathrm{a}$ & bcd & de & \\
\hline & Distilled water 1 & A 0 & A 0 & A 0 & A 0 & 0.000 & $\mathrm{~d} O$ \\
\hline & Distilled water I & i & $\mathrm{f}$ & $\mathrm{c}$ & $\mathrm{f}$ & $\mathrm{f}$ & do \\
\hline control & Tetractcline 2 & A 19 & B 16.67 & C 7 & A 20 & 15.67 & \\
\hline control & Tetracycline 2 & a & a & $\mathrm{b}$ & $\mathrm{a}$ & a & 1217 \\
\hline & Nystatin 3 & B4.67 & A 10 & A 10 & A 10 & $\begin{array}{l}8.67 \\
\text { cde }\end{array}$ & a 12.17 \\
\hline Aver & ge bacteria & $9.38 \mathrm{~A}$ & $7.52 \mathrm{~B}$ & $10.52 \mathrm{~A}$ & $8.92 \mathrm{AB}$ & & \\
\hline
\end{tabular}

* the numbers represent the average of three replicates

- similar large horizontal letters mean no significant differences between them at the probability (0.05).

- similar small vertical letters mean no significant differences between them at the of probability $(0.05)$. 
Table 2: Impact of Erodium moschatum extracts on the studied Fungal growth (mm)

\begin{tabular}{|c|c|c|c|c|c|c|c|}
\hline \multirow{2}{*}{ Extract } & \multirow{2}{*}{$\begin{array}{c}\text { Concentration } \\
\mathrm{mg} / \mathrm{ml}\end{array}$} & \multicolumn{4}{|c|}{ Fungal species } & \multirow{2}{*}{$\begin{array}{c}\text { Average } \\
\text { concentration }\end{array}$} & \multirow{2}{*}{$\begin{array}{c}\text { Average } \\
\text { extract }\end{array}$} \\
\hline & & F. oxysporeum & P. chrysogenum & T. mentagrophytes & M. canis & & \\
\hline \multirow{7}{*}{ Hot water } & & B 10 & $\mathrm{AB} 11.67$ & A 13 & C 7.33 & 10.50 & \multirow{6}{*}{ b 7.472} \\
\hline & 25 & $\mathrm{c}$ & $\mathrm{b}$ & bc & bcd & $\mathrm{b}$ & \\
\hline & & B 10 & A 12.67 & AB 11.33 & C 7.33 & 10.33 & \\
\hline & 50 & $\mathrm{c}$ & $\mathrm{b}$ & bc & bcd & $\mathrm{b}$ & \\
\hline & & В 10.33 & A 12.33 & A 12.33 & C 8 & 10.75 & \\
\hline & 100 & $\mathrm{c}$ & $\mathrm{b}$ & bc & bc & $\mathrm{b}$ & \\
\hline & 25 & A 10 & A 10 & A 11 & B 4.67 & 8.92 & \multirow{6}{*}{ b 6.602} \\
\hline \multirow{5}{*}{$\begin{array}{l}\text { Cool } \\
\text { water }\end{array}$} & 25 & $\mathrm{c}$ & b & bc & d & $\mathrm{b}$ & \\
\hline & 50 & B 10 & A 12.67 & AB 11 & C 4.67 & 9.59 & \\
\hline & 50 & $\mathrm{c}$ & b & bc & d & $\mathrm{b}$ & \\
\hline & 100 & B 1 & A 12 & AB 11 & C 6.67 & 9.92 & \\
\hline & 100 & $\mathrm{c}$ & b & bc & bc & $\mathrm{b}$ & \\
\hline \multirow{6}{*}{ Ethanol } & & A 7 & A 9.33 & A 10 & A 8.33 & 8.665 & \multirow{6}{*}{ b 6.292} \\
\hline & 20 & d & b & $\mathrm{c}$ & bc & $\mathrm{b}$ & \\
\hline & 50 & A 10 & A 9.33 & A 10 & A 8 & 9.332 & \\
\hline & 30 & c & b & $\mathrm{c}$ & bc & $\mathrm{b}$ & \\
\hline & & A 10 & A 9.33 & A 10 & A 9.33 & 9.665 & \\
\hline & 100 & c & b & c & $\mathrm{b}$ & $\mathrm{b}$ & \\
\hline \multirow{6}{*}{ Methanol } & & A 10 & A 10.67 & A 10.33 & B 4.67 & 8.92 & \multirow{6}{*}{ b 5.877} \\
\hline & $2 b$ & $\mathrm{c}$ & b & $\mathrm{c}$ & d & $\mathrm{b}$ & \\
\hline & 50 & A 10 & A 10.67 & A 10.67 & B 5 & 9.09 & \\
\hline & 50 & $\mathrm{c}$ & b & $\mathrm{c}$ & $\mathrm{cd}$ & $\mathrm{b}$ & \\
\hline & 100 & A 10 & A 11 & A 10.67 & C 5 & 9.17 & \\
\hline & 100 & c & b & $\mathrm{c}$ & $\mathrm{cd}$ & b & \\
\hline \multirow{6}{*}{ Glycoside } & 25 & A 12.33 & $\mathrm{AB} 10.33$ & A 13 & B9.33 & 11.247 & \multirow{6}{*}{ b 6.737} \\
\hline & 20 & bc & b & bc & $\mathrm{b}$ & b & \\
\hline & 50 & A 13.67 & AB 9.33 & AB 11.67 & B 8.67 & 10.84 & \\
\hline & 30 & b & b & bc & bc & $\mathrm{b}$ & \\
\hline & 100 & A 12.33 & AB 9.67 & A 12 & B 8.33 & 11.50 & \\
\hline & 100 & bc & b & & & $\mathrm{b}$ & \\
\hline \multirow{6}{*}{ Tannin } & 25 & AB 11.33 & B 10 & A 14.33 & C 5.67 & 10.33 & \multirow{6}{*}{ b 7.223} \\
\hline & 25 & bc & $\mathrm{b}$ & b & $\mathrm{cd}$ & $\mathrm{b}$ & \\
\hline & & A 11.33 & A 11 & A 12 & B 9.33 & 10.915 & \\
\hline & 50 & bc & b & $\mathrm{bc}$ & $\mathrm{b}$ & bbc & \\
\hline & 100 & A 11.67 & A 11.33 & A 14 & B 9 & 11.50 & \\
\hline & 100 & bc & b & d & $\mathrm{b}$ & b & \\
\hline \multirow{5}{*}{ control } & & A 0 & A 0 & A 0 & A 0 & 0.000 & \multirow{5}{*}{ a 33} \\
\hline & Distilled water I & $\mathrm{e}$ & $\mathrm{c}$ & d & $\mathrm{e}$ & c & \\
\hline & Nvstatin 2 & A 32 & A 33.33 & A 32.67 & A 33 & 33.000 & \\
\hline & Nystatum 2 & a & $\mathrm{a}$ & a & a & $\mathrm{a}$ & \\
\hline & age fungi & $11.099 \mathrm{~A}$ & $11.333 \mathrm{~A}$ & $12.05 \mathrm{~A}$ & B 8.116 & & \\
\hline
\end{tabular}

* the numbers represent the average of three replicates

- similar large horizontal letters mean no significant differences between them at the probability $(0.05)$.

- similar small vertical letters mean no significant differences between them at the of probability (0.05).

There is no significant variations among the extract concentrations in inhibition of the studied fungi compared to control 1 . The control 2 is the most effective in inhibiting fungi compared to the extract concentrations and control 1 with the average of $33 \mathrm{~mm}$. Concentration $100 \mathrm{mg} / \mathrm{ml}$ of ethylene with $9.33 \mathrm{~mm}$ diameter, $2 \mathrm{mg} / \mathrm{ml}$ of glycoside with $9.33 \mathrm{~mm}$ diameter and concentration 50 and $100 \mathrm{mg} / \mathrm{ml}$ of tannin with $9.33 \mathrm{~mm}$ and $9 \mathrm{~mm}$ diameter are the most effective in inhibition of $M$. can compared to control 1 and the and all concentrations. The concentrations 25 and $100 \mathrm{mg} / \mathrm{ml}$ of tannin with $14.33 \mathrm{~mm}$ and $14 \mathrm{~mm}$ diameter were the most effective inhibition of $T$. mentagrophytes compared to control 1 and all extract concentrations. However there was no significant difference among the extract concentrations in their effectiveness in inhibition of $P$. chrysogenum compared to control 1, while the concentration $50 \mathrm{mg} / \mathrm{ml}$ with $13.67 \mathrm{~mm}$ is the most effective in inhibiting the species F. oxysporeum compared to the control.
Table 3: Active chemical content of the $E$. moschatum

\begin{tabular}{ccccccc}
\hline \multicolumn{2}{c}{ E. moschatum } & \multicolumn{5}{c}{ Active compounds (ppm.) } \\
\hline Locality & \multicolumn{1}{c}{ Plant part } & Tannins & Quercetin & Catechin & Rutin & Kaempferol \\
\hline \multirow{2}{*}{ Saladin } & Whole plant & + & 0.092 & 0.002 & 1.68 & 0.17 \\
& Vegetative part & 0.007 & 0.043 & 0.002 & 0.22 & 0.002 \\
& flowers & 0.003 & 0.010 & 0.013 & 0.157 & + \\
& fruit & 0.012 & 0.011 & 0.049 & 0.604 & 0.002 \\
\multirow{2}{*}{ Sulaimanya } & Entire plant & 3.836 & 2.870 & 4.015 & 22.92 & 0.058 \\
\hline
\end{tabular}

$(+)$ means the compound with low concentrations

Results confirmed there is no significant difference among the six extracts of studied plants in their effect in inhibiting the examined fungi and no significant difference among $M$. canis, $T$. mentagrophytes, $P$. chrysogenum and $F$. oxysporeum affected by concentrations of plant extracts. 


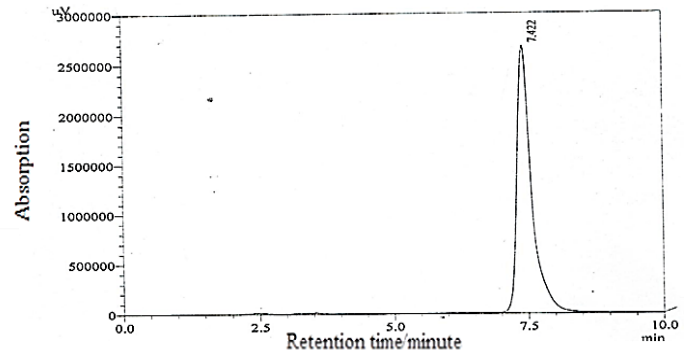

Figure 1. Tannin standard curve by HPLC of studied

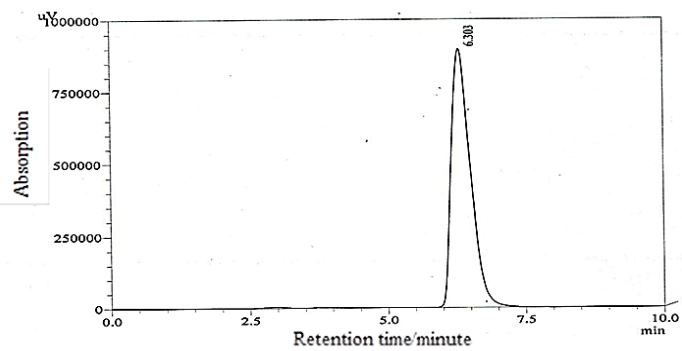

Figure 2. Quercetin standard curve by HPLC of

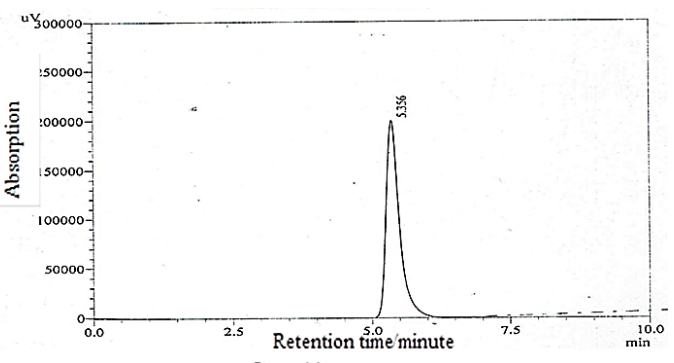

Figure 3. Catechin standard curve by HPLC of

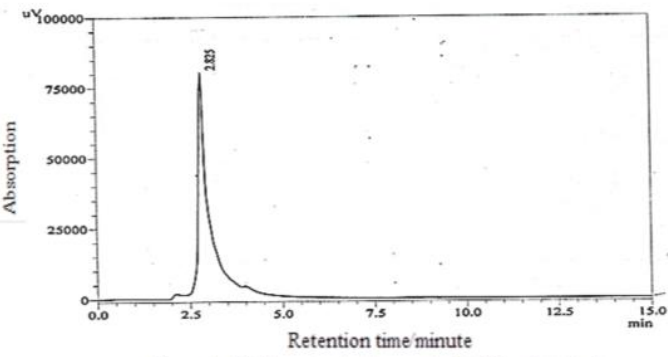

Figure 4. Rutin standard curve by HPLC of studied

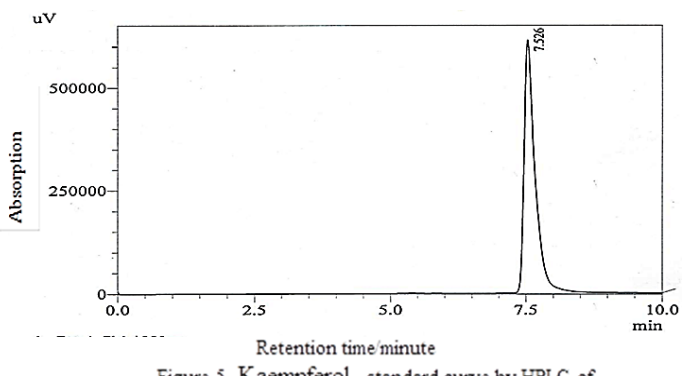

Figure 5. Kaempferol standard curve by HPLC of

Erodium species have been found to contain several types of flavonoids and glycosides that are effective in their anti-microbial activity, which are watersoluble (Öhretoulu, 2011 and Leyton, 2015), as for the hot water extract, the effectiveness against bacteria and fungi may be due to Gallic acid which is found in the family Orobanchaceae that dissolves in hot water $60 \mathrm{C}^{\circ}$ and has the effectiveness of antibacteria and fungi or may return to tannins due to the hot water is the best solvent used to isolate it (Ahmad, 1989 and Pantev et al., 2006). The inhibitory effect of the hot or cold water extract may be due to interference between the active compound or the interaction between the active compounds therefore it may reduce or increase the inhibitory activity against the microorganisms, the inhibitory activity may be due to some volatile oil dissolved in water. The inhibitory activity of ethane and methanol extracts is mainly due to the existence of active soluble compounds in alcohol, especially phenols such as flavonoids (quercetin and kaempferol), tannins and rutin or interaction with each other or with other active compounds dissolved in alcohol. Pantev et al., (2006) was indicated to that the anti-bacterial and fungal efficacy is due to the flavonoid content of the ethanol extract of tannins, rutin, quercetin and kampferol. The different effect of one plant extract on microorganisms activity varies according to the extraction method (Nostro, 2000), in water glycosides extract may be due to the role of glycoside, especially flavonoids (rutin) or nondiabetic part of the glycoside structure (Nostro, 2000 and Cowan, 1999). The scarcity of studies on glycoside content and its bioactivities of studied plants which requires further research and investigation. The anti-microbial activity of tannins is due to its ability to inhibit proteins transfer enzymes (transferase) existent in cell membrane, tannins are described as a group of phenol compounds and are classified into two groups: biodegradable tannins and intensive tannins, both of which have antimicrobial efficacy, it is highly effective in inhibiting the peroxidase enzyme and can interfere with the function of the cell wall (Scalbert, 1991 and Ukida et al., 2006).

\section{Active chemical content of the $E$. moschatum:}

The aerial plant parts of E. moschatum growing in Saladin and Sulaymaniyah contains all effective studied active compounds (table 3), the table showed that the whole plant growing in Saladin contains rutin at a higher concentration than the other studied active compounds at $1.68 \mathrm{ppm}$ followed by kaempferl $0.17 \mathrm{ppm}$, quercetin at $0.092 \mathrm{ppm}$ and catechin at $0.002 \mathrm{ppm}$, moreover vegetative parts of the plant contain rutin at a higher concentration than other active compounds at $0.22 \mathrm{ppm}$ followed by quercetin at $0.043 \mathrm{ppm}$, tannins $0.007 \mathrm{ppm}$, catechin $0.002 \mathrm{ppm}$ and kaempferl $0.002 \mathrm{ppm}$. In the flowers the rutin was higher than the rest of the active compounds at $0.157 \mathrm{ppm}$ followed by catechin $0.013 \mathrm{ppm}$, quercetin $0.010 \mathrm{ppm}$ and tannins $0.003 \mathrm{ppm}$. In the fruits the rutin with a higher concentration than others at a concentration of $0.604 \mathrm{ppm}$ followed by catechin at $0.049 \mathrm{ppm}$, quercetin, tannins and kaempferl at ppm $0.011,0.012$ and 0.002 respectively. In the entire plant growing in Sulaymaniyah the rutin has a higher concentration than others at ppm 22.92 followed by catechin at $4.015 \mathrm{ppm}$, tannins at 
$3.836 \mathrm{ppm}$, quercetin at $2.870 \mathrm{ppm}$ and kaempferl at $0.058 \mathrm{ppm}$. The whole plant growing in Sulaymaniyah contains tannins with higher concentration compared to the rest of the plant parts at a concentration of $3.836 \mathrm{ppm}$ followed by fruits at a $0.012 \mathrm{ppm}$, vegetative plant parts at $0.007 \mathrm{ppm}$ and flowers at 0.003 . Quercetin. Catechin and rutin are found at a higher concentration in the entire plant growing in Sulaymaniyah compared with the rest of the plant parts at concentration of ppm 2.870, 4.015, 22.92 and kaempferl with a higher concentration in the entire plant growing in Saladin at a concentration of $0.17 \mathrm{ppm}$. The whole plant growing in Sulaymaniyah has a higher concentration of tannins, quercetin, catechin, and rutin than other growing Saladin, the whole plant in Saladin has a higher concentration of kaempferl than of Sulaymaniyah.

Some of plant specimens contained different concentrations of flavonoids (quercetin, catechin, rutin and kaempferol) that is agreed with the study (Lin JH and Lin MF, 1997), which showed that E. moschatum contains several compounds (protocatechuic acid, Gallic acid, methyl Gallate, caffeic acid, brevifolincarboxylic acid and flavonoids (kaempferol, quercetin). Regarding the impact of the environment (locality) the study agreed with the results of (Dyubeni et al., 2012), which showed that the environment affected the quality and quantity of active compounds (volatile oils) in Pelargonium capitatum and Pelargonium radens as well as with the study (Abdul-Wahab, 2016) on Pelargonium graveolens which showed that the effective content varies according to the plant environment.

\section{References}

1. Abdul-Wahab MA, Toaima WIM. and Hamid ES, Effect of different planting locations in Egypt on volatile oil of geranium (Pelargonium graveolens L.) plant. Journal of basic and applied Research 2(4), 2016, 522-533.

2. Ahmad M and Nazil S, Studies on tannins from bark of pinus roxburghi. J . Chem. Soc. Pakis., 15, 1989, 213-217.

3. Al-Halfi MJA, A taxonomic study of the genus Erodium L. 'Herit (Geraniaceae) in Iraq. PhD thesis. Faculty of Science, University of Basra, Iraq, 2000.

4. Bautista M, Madrigal-Santillán E, MoralesGonzález A, Gayosso-del ucio JA, MadrigalBujaidar E, Chamorro-Cevallos G, Álvarez. G, onzález I, Benedi J, Aguilar-Faisal JL, MoralesGonzález JA, An Alternative hepatoprotective and Antioxidant agent: The Geranium,. Afr J Tradit Complement Altern Med., 12(4), 2015, 96-105.
5. Cowan MM, Plant products as antimicrobial agents. Clin. Microbiol. Rev.,12, 1999 564- 582.

6. Dyubeni L, Mayekiso B, and Magwa ML, A comparative study on essential oil yield and composition of rose-scented geranium (P. c. v. Rose) commercially grown on three different sites of the Amathole region in the eastern Cape, South Africa. African Journal of Agricultural Research, 7(43), 2012, 5842-5848.

7. Egorove NS, Antibiotics a scientific approach, Mir Publishers, 1985, Moscow.

8. Grand A, Verpoort R, Wondergem PA, and Pousset JL, Anti-infection phototherapies of tree-Sarannah Sengal (west-Africa). 11Antimicrobial activity of 33 species, J. Ethanopharmacol., 22, 1988, 25-31.

9. Igwenyi IO, and Elekwa AE, Phytochemical Analysis and Determination of Vitamin Contents of Geranium Robertianum. IOSR Journal of Dental and Medical Sciences (IOSR-JDMS). e-ISSN: 2279-0853, p-ISSN: 2279-0861.Volume 13, Issue 6 Ver. , 2016, 44-47.

10. Leyton SM, Beltramino JB, Evaluation of a Nipple Sealer Based on Brad Infusion. "Science Stays True Here .Biological and Chemical Research, Science Signpost Publishing, 2015, 345-355.

11. Lin JH and Lin MF, Tannins and related compounds from Erodium moschatum (L.) L'. Her . Journal of Food and Drug Analysis 5(4), 1997, 347-354.

12. Nostro N, Germano MP, dangeto V, Marino A and cannatelli MA, Extraction methods and bioautography for evaluation of medicinal plant antimicrobial activity. Letter in Applied Microbiology., 30, 2000, 379-384.

13. Öhretoulu D, Sakar MK and Sterner O, Polyphenolic compounds from Geranium purpureum Vill. growing in Turkey, Turk J Chem 35, 2011, 809-814.

14. Okuda T, Systematics and health effects of chemically distinct tannins in medicinal plants. Phytochem., 66, 2005, 2012-2031.

15. Pantev A, Ivancheva S, Staneva L and Serkedjieva J, Biologically Active Constituents of a Polyphenol Extract from Geranium sanguineum L. with Anti-Influenza Activity. Verlag der Zeitschrift für Naturforschung, Tübingen. Naturforsch. 61c, 2006 , 508-516. 
16. Petrova I, Petkova N, Ivanov I, Five Edible Flowers-Valuable Source of Antioxidants in Human Nutrition . International Journal of Pharmacognosy and Phytochemical Research; 8(4); 604-610.ISSN, 2016, 0975-4873.

17. Proestos C, Lytoudi K, Mavromelanidou O, Zoumpoulakis P, Sinanoglou VJ, Antioxidant Capacity of Selected Plant Extracts and Their Essential Oils . Antioxidants, 2, 11-22 . ISSN, 2013, 2076-3921.

18. Radulovic N, Dekic M and Stojanovic Radi' CZ, Chemical composition and antimicrobial activity of the essential oils of Geranium columbinum L. and G. lucidum L. (Geraniaceae). Turk J Chem. Tubitak, 2011, 499-512.

19. Scalbert A, Antimicrobial properties of tannins. Phytochem., 30, 1991, 3875-3883.

20. Seal T, Quantitative HPLC analysis of phenolic acids, flavonoids and ascorbic acid in four different solvent extracts of two wild edible leaves, Sonchus arvensis and Oenanthera linearis of
North-Eastern region in India. Journal of Applied Pharmaceutical Science Vol. 6 (02), 2016, 157-166

21. Ukida M, Akihisa T, Yasukawa K, Tokuda H, Suzuki $\mathrm{T}$ and Kimura $\mathrm{Y}$, Anti- inflammatory, anti-tumor promoting and cytotoxic activities of constituents of Marigold (Calendul aofficinallis) flowers. J. Nat. Prod., 96, 2006, 1692-1696.

22. Wagh VV, Datt B and Husain T, An Assessment of Diversity of Genus Geranium L. (Geraniaceae) in India with Special Emphasis on Indian Himalayan Region. Journal of Biodiversity Management and Forestry 4:2, 2015, 1-6.

\section{Cite this article as:}

Mostafa Qahtan Mosataf, Sirwan Hassan Salih, Talib Ouaid Alkhazraji. Impact of Erodium moschatum (L.) L.'Hér. extracts against some bacteria and fungi species. Annals of Plant Sciences 7.11 (2018) pp. 2456-2462.

do $\mathrm{http}: / /$ dx.doi.org/10.21746/aps.2018.7.11.3

Source of support: Nil 